\title{
Paranucleospora theridion (Microsporidia) infection dynamics in farmed Atlantic salmon Salmo salar put to sea in spring and autumn
}

\author{
S. Sveen ${ }^{1}$, H. Øverland ${ }^{1}$, E. Karlsbakk ${ }^{1,2}$, A. Nylund ${ }^{1, *}$ \\ ${ }^{1}$ Department of Biology, University of Bergen, Thormohlensgt 55, 5020 Bergen, Norway \\ ${ }^{2}$ Institute of Marine Research, PO Box 1870, Nordnes, 5817 Bergen, Norway
}

\begin{abstract}
The microsporidian Paranucleospora theridion (syn. Desmozoon lepeophtheirii) is a parasite of Atlantic salmon Salmo salar and also a hyperparasite of the salmon louse Lepeophtheirus salmonis. The parasite develops 2 types of spores in salmon, cytoplasmic spores in phagocytes and intranuclear spores in epidermal cells. The former type of development is assumed to be propagative (autoinfection), while the epidermal spores transfer the parasite to lice. Development in lice is extensive, with the formation of xenoma-like hypertrophic cells filled with microsporidian spores. We show that salmon are infected in the absence of lice, likely through waterborne spores that initiate infections in the gills. During summer and autumn the parasite propagates in the kidney, as evidenced by peaking normalised expression of $P$. theridion rRNA. Lice become infected during autumn, and develop extensive infections during winter. Lice mortality in winter and spring is likely responsible for a reservoir of spores in the water. Salmon transferred to sea in November (low temperature) did not show involvement of the kidney in parasite propagation and lice on such fish did not become infected. Apparently, low temperatures inhibit normal $P$. theridion development in salmon.
\end{abstract}

KEY WORDS: Microsporidian · Parasite $\cdot$ Hyperparasite $\cdot$ Salmon louse $\cdot$ Lepeophtheirus salmonis Spore development $\cdot$ Temperature

Resale or republication not permitted without written consent of the publisher

\section{INTRODUCTION}

The microsporidian parasite Paranucleospora theridion (syn. Desmozoon lepeophtheirii; see S. Nylund et al. 2011) is a parasite of Atlantic salmon Salmo salar and also is a hyperparasite of the salmon louse Lepeophtheirus salmonis (A. Nylund et al. 2009a,b, S. Nylund et al. 2010). P. theridion undergoes 2 types of development in salmon. Development occurs in the cytoplasm of epidermal cells and phagocytes, resulting in minute thin-walled spores assumed to be autoinfective. These cytoplasmic stages and spores are found in many tissues and organs and hence appear to represent a systemic infection in suitable host cells. A second type of sporogony is seen in epi- dermal cells in skin and gills only, where 1 to 2 thickwalled spores are produced inside the nucleus of the cells. These more robust spores ('environmental spores') are likely responsible for transferring the microsporidian infection to the salmon louse, as it feeds on salmon epidermis. Extensive propagation may occur in greatly enlarged infected cells in the lice, and infected cells with parasitic stages often occupy a large part of the louse volume. How the thick-walled spores produced in the lice infect salmon is unknown; few salmon individuals receiving infected lice in experiments contracted the infection (A. Nylund \& E. Karlsbakk, unpubl. obs.). Also, the infection dynamics and pathology in salmon is poorly understood. Heavy $P$. theridion densities in 
salmon are often associated with other diseases and diagnoses, and the parasite has been suspected of predisposing the host to other infectious agents and of being responsible for some of the pathology attributed to some viral diseases (S. Nylund et al. 2011). An association has been shown between $P$. theridion infection levels and the unspecific diagnosis 'proliferative gill inflammation' (PGI) in salmon (Steinum et al. 2010, S. Nylund et al. 2011).

In the present study, the infection dynamics of Paranucleospora theridion, as measured by quantitative real-time reverse-transcription PCR (RTPCR) analyses, was followed in 2 salmon farms following smolt sea-transfer in May and November, hence at times of increasing and decreasing water temperatures, respectively.

\section{MATERIALS AND METHODS}

\section{Sampling}

Atlantic salmon and salmon lice were collected at intervals over a period of 1 yr from 2 farms located in Sogn og Fjordane county, western Norway. The smolts at Farm A were put to sea in May, while the smolts in Farm B were sea-launched in November. Mortality, temperature and oxygen levels were measured at both sites throughout the sampling period.

The origin of the eggs for the salmon at Farm A was the brood fish company Salmobreed. The smolt was produced at a land-based site in Sogn og Fjordane county before being put to sea in a farm in the same county on 10 May 2009. This farm, located at a site with the dominating current going in one direction, consists of 4 ring nets with a diameter of $157 \mathrm{~m}$ and a depth of $70 \mathrm{~m}$ under the rings. The previous production at this site ended 31 October 2008. The farm was kept empty until 10 May 2009, when new smolt was stocked at the site. Delousing was carried out at the site in November 2009 and April 2010. Temperature was measured daily at $5 \mathrm{~m}$ depth.

The smolts that were sea-launched at Farm B were produced at a land-based site in Hordaland county from eggs supplied by the brood fish company AquaGen. Farm B consists of 10 steel cages $(25 \times 25 \mathrm{~m})$, and the depth under the farm ranged from 40 to $70 \mathrm{~m}$. A unidirectional sea current is dominating at the site. The previous production at this site ended 17 June 2009. New production at this site started 1 October 2009, but the fish included in the present study were sea-launched on 1 November 2009. The first samples ( $n=30$ ) were taken at the arrival of these fish. At this time the smolt had been exposed to full seawater, in a well boat, for $<12 \mathrm{~h}$ during transport from the smolt site to Farm B. Shortly after sea-launching, mortalities increased and the fish were diagnosed with infectious pancreatic necrosis (IPN) by the responsible veterinary service. The salmon were deloused on 12 December 2009. Temperature was measured at $4 \mathrm{~m}$ depth.

A total of 136 salmon in 9 samples from Farm A and 130 salmon in 5 samples from Farm B were examined (Table 1). Salmon lice Lepeophtheirus salmonis were also collected, if present. Since the prevalence of Paranucleospora theridion in Farm A was 100\% in both September and November, the number of fish taken for analysis was reduced from 30 to 10 fish on the remaining sampling dates (6 fish in June) until the termination of the study period.

Gill and kidney tissues were sampled from all fish and stored at $-80{ }^{\circ} \mathrm{C}$ for later analysis using real-time RT-PCR for detection of pathogens.

\section{RNA and DNA extraction}

RNA was extracted from both gills and kidney of salmon as described by Devold et al. (2000), except that Isol RNA Lysis Reagent (5-PRIME) was used instead of TRIZOL (Gibco BRL). The concentration of the resulting RNA was measured using a NanoDrop ${ }^{\circledR}$

Table 1. Salmo salar and Lepeophtheirus salmonis. Samples collected at 2 salmon farms (date of sea transfer indicated in parentheses). n: number of specimens sampled

\begin{tabular}{|c|c|c|c|}
\hline $\begin{array}{l}\text { Sampling date } \\
\text { (dd/mm/yy) }\end{array}$ & $\underset{(\mathrm{n})}{\text { Salmon }}$ & $\begin{array}{l}\text { Salmon length } \\
\text { (cm) (min.-max.) }\end{array}$ & $\begin{array}{l}\text { Lice } \\
\text { (n) }\end{array}$ \\
\hline \multicolumn{4}{|c|}{ Farm A (10/05/09) } \\
\hline 12/07/09 & 20 & $25(21-30)$ & 6 \\
\hline 24/09/09 & 30 & $40(30-49)$ & 10 \\
\hline 05/11/09 & 30 & $43(29-51)$ & 10 \\
\hline 09/12/09 & 10 & $44(39-50)$ & 10 \\
\hline $14 / 01 / 10$ & 10 & $47(40-53)$ & 10 \\
\hline $18 / 02 / 10$ & 10 & $50(39-57)$ & 10 \\
\hline 09/04/10 & 10 & 53 (48-69) & 10 \\
\hline $24 / 06 / 10$ & 6 & $61(55-70)$ & $0^{\mathrm{a}}$ \\
\hline $17 / 08 / 10$ & 10 & $58(52-69)$ & $0^{\mathrm{a}}$ \\
\hline \multicolumn{4}{|c|}{ Farm B $(01 / 11 / 09)$} \\
\hline 01/11/09 & 30 & $19(16-22)$ & $30^{\mathrm{b}}$ \\
\hline 04/12/09 & 30 & $21(17-25)$ & 10 \\
\hline $04 / 01 / 10$ & 30 & $23(18-30)$ & $0^{\mathrm{c}} / 10^{\mathrm{b}}$ \\
\hline 01/03/10 & 30 & $21(18-28)$ & 10 \\
\hline 02/09/10 & 10 & $54(50-58)$ & $0^{\mathrm{a}}$ \\
\hline \multicolumn{4}{|c|}{$\begin{array}{l}{ }^{a} \text { Lice present on the fish, not analysed; }{ }^{b} \text { Lice from fish } \\
\text { transferred to sea } 01 / 10 / 09 ; \\
\text { lice from neighbouring pens }\end{array}$} \\
\hline
\end{tabular}


ND-1000 spectrophotometer. DNA was extracted from whole sea lice following the addition of $2 \mu \mathrm{l}$ suspension of the archaean Halobacterium salinarum acting as an exogenous control. The DNeasy DNA Tissue kit (Qiagen) was used according to the manufacturer's recommendations.

\section{PCR}

Extracted DNA from tissues of salmon and salmon lice were used to obtain the partial rRNA small subunit (rRNA SSU) sequence of Paranucleospora theridion using the primers Nuc-F (5'-CGG ACA GGG AGC ATG GTA TAG-3') and Nuc-R5 (5'-TCC CAT CAA TTT CCA ACG GC-3'), yielding a fragment of ca. 370 to $400 \mathrm{bp}$ when excluding the ends.

The PCR reaction mixture $(50 \mu \mathrm{l})$ contained $1 \times$ ThermoPol reaction buffer (New England BioLabs), $10 \mathrm{mM}$ of each dNTP (Promega), $0.4 \mu \mathrm{M}$ of each primer (Invitrogen), 1 U Taq DNA polymerase (New England BioLabs) and approximately 200 to $300 \mathrm{ng}$ of DNA template. Amplification was performed in a GeneAmp PCR System 9700 machine (Applied Biosystems) with initial denaturation at $95^{\circ} \mathrm{C}$ for $5 \mathrm{~min}$; followed by 35 cycles of $95^{\circ} \mathrm{C}$ for $30 \mathrm{~s}, 53^{\circ} \mathrm{C}$ for $45 \mathrm{~s}$, and $72^{\circ} \mathrm{C}$ for $1 \mathrm{~min}$; final extension at $72^{\circ} \mathrm{C}$ for $7 \mathrm{~min}$, and a short storage at $4^{\circ} \mathrm{C}$. All PCR products were purified with EZNA PCR cycle pure (Omega Biotek), and sequenced using the Big Dye terminator sequencing kit (Applied Biosystems). Sequencing was performed at the sequencing facility at the University of Bergen (http://seqlab.uib.no/). Sequence data were analysed and assembled using VectorNTI software (Informax). Sequences obtained in the present study were submitted to GenBank.

Real-time assays (TaqMan probes) for Paranucleospora theridion (Nuc assay) and elongation factor $1 \alpha\left(\right.$ EF1A $_{\mathrm{A}}$ assay) (see S. Nylund et al. 2010) was used on samples from salmon, with $\mathrm{EF}_{1 \mathrm{~A}_{\mathrm{A}}}$ as internal control (reference gene). The VersoTM 1-step QRT-PCR kit from Thermo Scientific was used. All assays were run in a total volume of $12.5 \mu$ with $2 \mu \mathrm{l}$ template, at 45 cycles in an ABI 7500 Sequence Detection System real-time thermocycler as described by S. Nylund et al. $(2010,2011)$. The runs were considered positive when the fluorescence signal increased above a set threshold of 0.015 . Analyses included non-template controls (NTC), RNA extraction and positive controls. In analyses with the Nuc assay of sea-lice samples, the SAL assay was used with an external control, as described by S. Nylund et al. (2010). The repro- ducible detection limit for the Nuc assay is at a cycle threshold $\left(\mathrm{C}_{\mathrm{T}}\right)$ value of 37 (see $\mathrm{S}$. Nylund et al. 2010), representing <1 spore (S. Nylund et al. 2011). The equations for the standard curves, based on triplicates of 10-fold serial dilutions of template, were $\mathrm{C}_{\mathrm{T}}=-3.51 \times(\log \mathrm{RNA}$ dilution $)+18.38$ for the EF1 $A_{A}$ assay $\left(R^{2}=0.996\right)$, and $C_{T}=-3.53 \times(\log R N A$ dilution $)+19.70$ for the Nuc assay $\left(R^{2}=0.997\right)$. Efficacies $\left(\mathrm{E}=10^{1 /(- \text { slope) }}\right)$ were 1.921 and 1.987 , respectively. Analyses resulting in $\mathrm{C}_{\mathrm{T}}$ values in the range 37.0 to 37.9 were rerun in triplicate, and considered positive when all were positive. The exogenous and endogenous controls were used for calculation of the normalised expression (NE) of SSU rRNA from P. theridion (S. Nylund et al. 2010). This measure of parasite density was used as a proxy of abundance, with NE in negative samples set at 0 .

\section{Analyses}

Temporal change in prevalence was examined using Fisher's exact test (FET) in Quantitative Parasitology 3.0, with post hoc pairwise comparison of samples also using FET if overall changes were significant. The nonparametric Kruskal-Wallis test (KW; in Statistica 10.0) was used to test for temporal changes in Paranucleospora theridion density. Post hoc comparisons were done with the bootstrap test for changes in abundance in Quantitative Parasitology 3.0 ( $\mathrm{p}$-values given in the text).

\section{RESULTS}

\section{Farm A}

Farm A was studied from 12 July 2009 to 17 August 2010. Average monthly temperature was high (ca. $16^{\circ} \mathrm{C}$ ) in July-August 2009 followed by a gradual decrease to a minimum of $4.5^{\circ} \mathrm{C}$ in March 2010. Temperature increased thereafter, reaching $18.2^{\circ} \mathrm{C}$ in August 2010. The behaviour and appearance of the fish was normal throughout, except in September 2009, when abnormal behaviour was apparent, particularly highly increased jumping frequencies and signs of skin irritation (excess mucus production). The cause was not revealed; no disease agents were detected by the responsible veterinary service. In addition to gill and kidney samples, skin samples from 7 fish were analysed for Paranucleospora theridion (Nuc assay) this month, and high densities of the parasite were detected. 
Paranucleospora theridion in salmon

Paranucleospora theridion prevalence increased significantly from July to September 2009 (to 100\%), when based on both gill ( $\mathrm{p}<0.001)$ and kidney $(\mathrm{p}<$ 0.001) sample analyses (Fig. 1A). Prevalence stayed at $100 \%$ in the gill samples, while a few uninfected fish occurred in the kidney samples from February to June 2010. Parasite density (NE) also increased significantly in the period July to September 2009 in both tissues $(\mathrm{p}<0.01)$. In the period September to November 2009, there was a significant decrease in density in the gills ( $p<0.01$ ) followed by further gradual decrease until the June sample, where the step from December to January was significant ( $\mathrm{p}<$ 0.05). A slight increase from April-June to the August sample in 2010 was not significant $(p=0.06)$. In the kidney samples, parasite density did not change from September to December 2009. A gradual decrease occurred in the period November to April ( $p<0.01$ ).

The increase in average NE from July to September was 3.4-fold in the gill and 31-fold in the kidney samples. The decrease in average NE from September 2009 to June 2010 was ca. 3020-fold in the gill and ca. 540-fold in the kidney samples.
Paranucleospora theridion in lice

Prevalence of Paranucleospora theridion in lice Lepeophtheirus salmonis varied significantly during the period July 2009 to April 2010 (FET, p < 0.001) (Fig. 1B). A low prevalence from July to September 2009 was followed by an increase ( $p<0.001$ ) to $100 \%$ in the samples from November 2009 to January 2010. A significant decrease ( $p=0.001$ ) occurred during spring, with 2 out of 10 lice being infected in April. $P$. theridion density (NE) in the lice was similarly very low from July to September 2009, followed by a marked increase in the November sample $(\mathrm{p}<0.05)$. Mean NE decreased from the winter samples at similar levels (November to January) to April 2010 ( $\mathrm{p}<0.01$ ).

\section{Farm B}

Farm B was studied from 1 November 2009 (sea transfer) to 1 March 2010. An additional sample, collected on 2 September 2010 from the same pen-population, was also analysed for comparison. Average monthly temperature was highest in November $\left(9.7^{\circ} \mathrm{C}\right.$, maximum: $\left.10.1^{\circ} \mathrm{C}\right)$ and gradually decreased until March (December: $9.3^{\circ} \mathrm{C}$, January: $7.4^{\circ} \mathrm{C}$, February: $4.5^{\circ} \mathrm{C}$, March: $3.9^{\circ} \mathrm{C}$; minimum: $3.8^{\circ} \mathrm{C}$ on 22 February). Increasing mortality was observed following sea transfer in November and persisted through February. This mortality was ascribed to IPN by the responsible veterinary service.

Paranucleospora theridion in salmon

Prevalence of Paranucleospora theridion in gill samples varied significantly ( $p<0.001$ ) (Fig. 2). A marked increase occurred from $13 \%$ immediately after sea transfer in November to $100 \%$ in December $(\mathrm{p}<0.001)$. Prevalence at $100 \%$ was also observed in January, followed by a decrease to $83 \%$ in March ( $\mathrm{p}<0.05)$. Mean NE levels were very low compared to those observed in Farm A. A significant increase in observed mean NE was found in the gill samples from November to December 2009 ( $\mathrm{p}$ < 0.02). A further increase from Decem-
Fig. 1. Paranucleospora theridion infecting Salmo salar and Lepeophtheirus salmonis. P. theridion normalised expression (NE) and sample prevalence in (A) farmed Atlantic salmon gill and kidney samples and (B) salmon lice in Farm A from July 2009 to August 2010. Error bars for mean NE represent bootstrapped $95 \%$ confidence intervals; kidney values in (A) were displaced $(+2 \mathrm{~d})$ to avoid overlapping error bars 


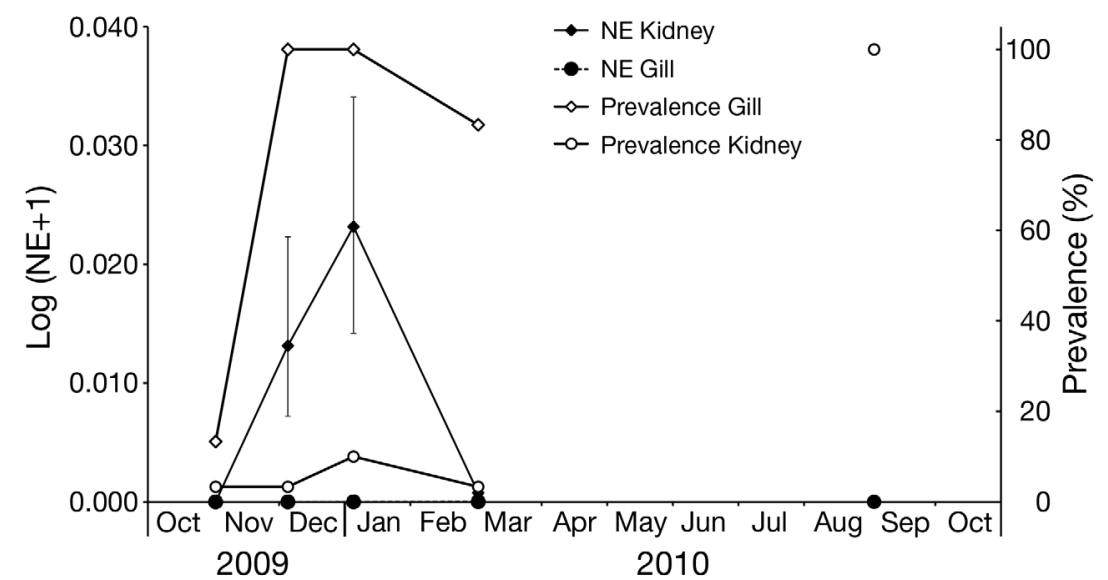

Fig. 2. Paranucleospora theridion infecting Salmo salar. P. theridion normalised expression (NE) and sample prevalence in farmed Atlantic salmon gill and kidney samples in Farm B from November 2009 (sea transfer) to March 2010, with an additional observation in September 2010. Error bars for NE represent bootstrapped $95 \%$ confidence intervals

ber 2009 to January 2010 was not significant, but a decrease occurred from January to March $(p<0.01)$. Prevalence and mean NE based on analyses of the kidney samples was low, and did not vary significantly in the period November to March. However, a sample from the same fish group on 2 September 2010, i.e. 6 mo later, showed $100 \%$ prevalence of $P$. theridion in the kidney samples, but mean NE was low (not significantly different from the March sample).

\section{Paranucleospora theridion in lice}

Analyses of lice from Farm B during the study period (November to March) revealed only a single positive specimen, in the November sample (NE of Paranucleospora theridion was low).

\section{Sequences}

Partial rRNA SSU sequences of Paranucleospora theridion were obtained in order to verify the identity of the templates detected by the Nuc assay. The following sequences were obtained (GenBank accession numbers): Farm A: salmon: September (HM 231163), November (HM231161 and HM231162), January (HM231159 and HM231160); salmon lice: November, December, January, February (HM23 1155 to HM231158, respectively); Farm B: salmon: January (HM231164). It was not possible to sequence $P$. theridion from the single weakly positive salmon louse detected in Farm B. The 10 sequences did not show any variation.

\section{DISCUSSION}

Paranucleospora theridion shows 2 developmental cycles in Atlantic salmon. One type of development (type I) has been observed in the cytoplasm of phagocytes and in epidermal cells, and results in the production of numerous small thin-walled spores with a very short polar tube. Infected cells have been observed to degenerate, hence releasing these small spores into the host organism (S. Nylund et al. 2010). These spores are considered autoinfective, likely being phagocytised by phagocytes where the short polar tube may be responsible for the delivery of the sporoplasm to the phagocyte cytoplasm and hence initiating a new cycle of development. Real-time PCR studies on $P$. theridion tissue tropism supports such an interpretation; the parasite produces a systemic infection and only type I development has been observed in tissues other than the epidermis. Type II development occurs in the nuclei of epidermal cells, where 1 to 2 thick-walled spores with a long polar tube are produced. These spores ('environmental spores') have been considered responsible for transferring the infection to salmon lice, since these copepods must devour large numbers of them when feeding on the salmon skin. Development of the microsporidian in the lice represents a third type of sporogony, and may result in the copepod being packed with $P$. theridion spores (Freeman et al. 2003, Freeman \& Sommerville 2009, A. Nylund et al. 2009a,b,c, S. Nylund et al. 2010). However, the events in the $P$. theridion life cycle leading to transmission from lice to salmon are unknown. No likely mode of direct spore release from infected lice to the salmon has been described; there is no evidence for spore transmission via the lice mouth or release via the gut (Freeman \& Sommerville 2009, S. Nylund et al. 2010). Hence it appears likely that infected lice release their spore contents to the water post-mortem.

The present study showed that salmon put to sea in November (Farm B) may become infected immediately by the parasite, as evidenced by real-time PCR positive gill samples. Since no direct contact with lice can be responsible for the infections appearing in 
Farm B, the likely source is waterborne spores. Lice collected at the farm (other pens) at this time were also generally uninfected, and the single louse found positive for the parasite showed a very weak signal (November sample). It appears likely that this positive signal represents salmon tissues in the louse gut. In Farm A, infections in the lice showed a marked increase in prevalence and NE during the period September to November, which likely represents infections established through ingestion of epidermal intranuclear spores from the salmon. The propagation of the parasite in the lice results in xenoma-like hypertrophic cells visible through the exoskeleton of live lice (e.g. Freeman et al. 2003), and such lice were commonly observed during winter in the present study (Farm A).

There was a clear difference in the observed infection dynamics in salmon between Farm A (stocked 10 May) and Farm B (stocked 1 November). In Farm A an increase in Paranucleospora theridion density in gill samples in summer was accompanied by increased amounts of the parasite in the kidney. During the period autumn-winter-spring, the parasite density decreased in the gill samples, while remaining high from September to December in the kidney before declining in the spring. Hence kidney infections occurred with a propagation of the parasite that is likely critical for the initiation of a secondary intranuclear developmental sequence in the epidermis. Intranuclear epidermal spores are considered infective to the salmon lice (see previous paragraph). In Farm B, increasing densities of the parasite were observed in gill samples after sea transfer and they peaked in January, but were not accompanied by elevated levels of the parasite in the kidney and sea lice from the fish that remained uninfected. It appears likely that this difference is due to a failure in the parasite development at low temperatures during winter; autoinfection is inhibited and spores that may infect the lice are not produced. Since seawater temperature was $\leq 10^{\circ} \mathrm{C}$ after sea transfer, such temperatures seem to arrest the initial development of $P$. theridion infections in salmon. There was no evidence for propagation of the parasite in the kidney, as observed in Farm A and by S. Nylund et al. (2010). In Farm A, temperatures below $10^{\circ} \mathrm{C}$ were not seen until late in November, and were 14.5 to $17.1^{\circ} \mathrm{C}$ in the period July to September when parasite propagation was evidenced in the salmon, and 10.5 to $15.2^{\circ} \mathrm{C}$ in the period September to November when parasite propagation occurred in salmon lice.

Microsporidian development may be highly temperature-dependent (see Sanchez et al. 2000). Kaba- tana takedai infections in salmonids do not develop at $9^{\circ} \mathrm{C}$, and are reduced at $11^{\circ} \mathrm{C}$. Normal development occurs at 13 to $17^{\circ} \mathrm{C}$ (Zenke et al. 2005). Antonio \& Hedrick (1995) found that Nucleospora salmonis infections in Chinook salmon Oncorhynchus tshawytscha are not completely arrested at $9^{\circ} \mathrm{C}$ but infections are less severe and mortality low. In these cases the stages in the development of the parasites affected by temperature is not known. Beaman et al. (1999) found that normal development of Loma salmonae is interrupted by temperatures below $9^{\circ} \mathrm{C}$ as well as above $20^{\circ} \mathrm{C}$, when xenoma formation in the gills is inhibited. At low temperature, the parasite arrives in the heart where an initial merogony normally occurs, but xenoma formation in the gills does not occur and the gills eventually become PCR-negative by 4 wk post-challenge (Sanchez et al. 2000, 2001). Apparently, normal proliferation in the heart is arrested by low temperatures. This observation appears similar to the present one, in the sense that a propagative phase is inhibited so the subsequent production of environmental spores does not occur. This interpretation assumes that the lack of infections in the sea lice from Farm B was due to an absence of infective epidermal spores in the salmon. Following infection (detected in the gills), the density of the parasite also increased in kidney samples (Farm A). It seems likely that epidermal cells become infected through contact with waterborne spores, injecting sporoplasms into the cytoplasm of the cells. This first cycle of cytoplasmic development in epidermal cells likely releases autoinfective spores that are taken up by phagocytes (see S. Nylund et al. 2010). Antigentrapping phagocytes moving to the kidney are likely responsible for initiating infections there and the observed parasite propagation. It is interesting that gill inflammation with phagocytosis of the autoinfective spores may be important for the spread of the parasite from the gills to the kidney and other tissues. Paranucleospora theridion infections have been found to be closely associated with PGI (Steinum et al. 2010, S. Nylund et al. 2011).

Some of the salmon in Farm A, put to sea on 10 May, had already become infected in our first sample of 12 July. However, a clear increase in prevalence shows that transmission of the parasite to salmon also occurred at this site during autumn. Signs of irritation were apparent in the salmon in September, and exposure to Paranucleospora theridion spores may possibly be responsible. Further experimental studies are needed on the effects of $P$. theridion infections on salmon, including potential effects on the immune system caused by parasite exploitation of phago- 
cytes, possibly affecting susceptibility to other disease agents and prognosis following other infections (see S. Nylund et al. 2011).

\section{LITERATURE CITED}

Antonio DB, Hedrick RP (1995) Effect of water temperature on infections with the microsporidian Enterocytozoon salmonis in chinook salmon. Dis Aquat Org 22:233-236

Beaman HJ, Speare DJ, Brimacombe M (1999) Regulatory effects of water temperature on Loma salmonae (Microspora) development in rainbow trout. J Aquat Anim Health 11:237-245

Devold M, Krossøy B, Aspehaug V, Nylund A (2000) Use of RT-PCR for diagnosis of infectious salmon anaemia virus (ISAV) in carrier sea trout Salmo trutta after experimental infection. Dis Aquat Org 40:9-18

Freeman MA, Sommerville C (2009) Desmozoon lepeophtherii n. gen., n. sp., (Microsporidia: Enterocytozoonidae) infecting the salmon louse Lepeophtheirus salmonis (Copepoda: Claigidae). Parasites Vectors 2:58

Freeman MA, Bell AS, Sommerville C (2003) A hyperparasitic microsporidian infecting the salmon louse, Lepeophtheirus salmonis: an rDNA-based molecular phylogenetic study. J Fish Dis 26:667-676

Nylund A, Watanabe K, Nylund S, Arnesen CE, Karlsbakk E (2009a) New pathogen - old disease. Norsk Fiskeoppdrett 34(2):44-49 (in Norwegian with English Abstract)

Nylund A, Watanabe K, Nylund S, Arnesen CE, Karlsbakk E (2009b) Salmon lice act as vectors for a new species of microsporidian. Norsk Fiskeoppdrett 34(6a):20-23 (in Norwegian with English Abstract)

Editorial responsibility: Dieter Steinhagen,

Hannover, Germany
Nylund A, Watanabe K, Nylund S, Sæevareid I, Arnesen CE, Karlsbakk E (2009c) Salmon lice-biological vector for salmon parasite. Naturen 133:217-222 (in Norwegian with English Abstract)

Nylund S, Nylund A, Watanabe K, Arnesen CE, Karlsbakk E (2010) Paranucleospora theridion n. gen., n. sp. (Microsporidia, Enterocytozoonidae) with a life cycle in the salmon louse (Lepeophtheirus salmonis, Copepoda) and Atlantic salmon (Salmo salar). J Eukaryot Microbiol 57:95-114

Nylund S, Andersen L, Sævareid I, Plarre H and others (2011) Diseases of farmed Atlantic salmon Salmo salar associated with infections by the microsporidian Paranucleospora theridion. Dis Aquat Org 94:41-57

Sanchez JG, Speare DJ, Markham RJF (2000) Normal and aberrant tissue distribution of Loma salmonae (Microspora) within rainbow trout, Oncorhynchus mykiss (Walbaum), following experimental infection at water temperatures within and outside of the xenoma-expression temperature boundaries. J Fish Dis 23:235-242

Sanchez JG, Speare DJ, Markham RJF, Wright GM, Kibenge FSB (2001) Localization of the initial developmental stages of Loma salmonae in rainbow trout (Oncorhynchus mykiss). Vet Pathol 38:540-546

Steinum T, Kvellestad A, Colquhoun DJ, Heum M, Mohammad S, Nygaard Grøntvedt R, Falk K (2010) Microbial and pathological findings in farmed Atlantic salmon Salmo salar with proliferative gill inflammation. Dis Aquat Org 91:201-211

Zenke K, Urawa S, Fujiyama I, Yokoyama H, Ogawa K (2005) Effects of water temperature on infection of the microsporidian Kabatana takedai in salmonids. Fish Pathol 40:119-123

Submitted: December 15, 2011; Accepted: March 12, 2012 Proofs received from author(s): August 9, 2012 